\title{
AMHTS における超音波検査で発見された腎腫瘍
}

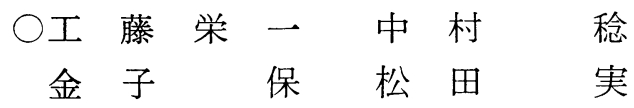

\section{はじめに}

当センターでは, 超音波検査の有用性を認め1981年 4 みより検索できなかった結果ではないかと思われる。 次にその他の腎異常とされた 88 例を見ると，腎腫瘍疑 月より，肝胆道系のスクリーニングを実施してきたが， 1983年超音波検查中に偶然，右腎腫瘍を発見する事が出 来たので腎のスクリーニングの必要性を感じ，同年 5 月 より肝胆道系に加えて腎のスクリーニングも実施してき た。その後1984年 7 月までに行こなった腎のスクリーニ ングの結果について報告する。

\section{方法及び結果}

使用した装置は,リニア電子走查型超音波装置, 東芝 SLA $30 \mathrm{~A}$ と SAC $12 \mathrm{~A}$ である。

検查方法は，絶食時に右肋骨弓下，右肋間及び左肋間 より両側の腎を検查した。検查対象は，1983年 5 月より 1984年 7 月まで当センターの健診を受けた総受診者, 14, 206名である。

腎に括けるスクリーニングの結果を示すと，異常を認 めなかったものは，13，459例（94.7\%）で異常所見者数 は747例 $(5.3 \%)$ である。この内訳を見ると腎のう胞 473 例 $(3.3 \%)$ 腎結石 14 例 $(0.1 \%)$ 腎結石疑い70例 $(0.5$ $\%$ ）重複腎盂15例 $(0.1 \%)$ 重複腎孟疑い56例 $(0.4 \%)$ 腎描出不能15例 $(0.1 \%)$ 腎摘出術後15例 $(0.1 \%)$ 尿管 結石 1 例，その他の腎異常88例 $(0.6 \%)$ となっている。 この異常所見者数を左右別に歹ると右腎452例，左腎259 例之なって扮り，右腎に多く発見されている。これは右 腎が 2 方向から検索できるのに対して，左腎は一方向の い30例 (34.1\%) 腎結石又は石灰化疑い15例（17.0\%） 水腎症疑い15例 $(17.0 \%)$ 腎の5胞疑い12例（13.6\%） 腎内不明エュー7 例 $(8.0 \%)$ 腎变形疑い6 例 $(6.8 \%)$ 重複腎孟疑い 3 例 $(3.4 \%)$ となっている。この30例の 腎腫瘍を疑ったものの内, 当院で 2 次検査をらけたもの は14例で残り16例については該当者が来院しなかった等 の理由により追跡調查が行兄なかった。

追跡調查の出来た14例の結果を示すと, 右腎悪性腫瘍 4 例, 右腎脂肪腫 3 例, 左腎脂肪腫 1 例, 正常右 1 例, 左 4 例, 左腎孟拡張 1 例となっており 4 例の腎悪性腫瘍 を発見できた。この 4 症例の腎悪性腫瘍の尿所見の内訳 は, 2 症例は蛋白陽性, 潜血反応陽性で 1 症例は潜血反 応弱陽性である。のこりの 1 症例については, 尿に異常 所見を認めなかった症例で超音波検査の有用性が認めら れた症例である。

\section{まとめ}

以上の上うに超音波検查は，肝胆道系と同様，腎にお いても有用性があり自動化健診においては, 副作用もな く簡単に行こな兄る重要な検查のひとつであると考兄 る。また， 4 症例の腎悪性腫瘍のらち 3 症例について は，尿検查により蛋白及び潜血反応陽性を指摘されてお括 り 2 次検査においても重要な役割を占める検查法である と考㝋られる。

\footnotetext{
Studies on renal cancer found by ultrasonio examination in AMHTS
}

横浜総合健診センター 